\title{
Pengaturan Peninjauan Kembali Dalam Perspektif Sistem Peradilan Pidana di Indonesia
}

\author{
Nys. Arfa, Syofyan Nur, Tri Imam Munandar \\ Fakultas Hukum, Universitas Jambi, Indonesia \\ Email corresponding author: nys_arfa@yahoo.com
}

\begin{abstract}
ABSTRAK
Tujuan penelitian ini adalah, pertama, untuk mengetahui, menganalisis serta mengkritisi pengaturan permohonan Peninjauan Kembali (PK) yang diajukan oleh Jaksa Penuntut Umum (JPU) dalam perspektif sistem peradilan pidana di Indonesia. Kedua, untuk menemukan dan menganalisis pengaturan mengenai permohonan PK yang ideal kedepannya dalam perspektif sistem peradilan pidana di Indonesia. Berpijak dari tujuan penelitian tersebut, maka dirumuskanlah 2 (dua) permasalahan yaitu: (1) Bagaimanakah pengaturan permohonan PK yang diajukan oleh JPU dalam perspektif sistem peradilan pidana di Indonesia? (2) Bagaimanakah pengaturan PK dalam perspektif sistem peradilan pidana di Indonesia untuk kedepannya?. Metode penelitian yang dipergunakan dalam melakukan pembahasan dari permasalahan yang telah dirumuskan tersebut adalah metode penelitian normatif dengan pendekatan konseptual, perundang-undangan, sejarah dan kasus hukum. Setelah dilakukan penelitian, maka hasil yang diperoleh, pertama, dalam perspektif sistem peradilan pidana di Indonesia JPU berhak mengajukan permohonan PK terhadap putusan yang telah berkekuatan hukum tetap, dengan prinsip dasarnya menguntungkan terpidana atau ahli warisnya, namun hal yang demikian ini tidaklah bersifat mutlak, karena dalam keadaan tertentu dapat pula diajukan permohonan PK oleh JPU terhadap putusan yang telah berkekuatan hukum tetap jika tidak terwujudnya kebenaran materil, dalam hal ini permohonan PK tersebut kemungkinan besar justru akan memberatkan terpidana; Kedua, pengaturan mengenai upaya hukum PK yang ideal untuk kedepannya agar JPU diberikan hak secara tegas untuk mengajukan permohonan PK di dalam ketentuan Pasal 263 KUHAP, baik dalam kapasitasnya untuk meringankan maupun yang memberatkan terpidana. Sehingga rekomendasi yang ditawarkan dari adanya penelitian ini adalah, pertama, dalam perspektif sistem peradilan pidana hendaknya antara terpidana dan JPU diberikan hak secara berimbang di dalam upayanya menggunakan sarana hukum PK; kedua, jika pembentuk undang-undang menghendaki adanya penghilangan hak dari JPU di dalam upayanya mengajukan permohonan PK secara tuntas, yang sekiranya dapat merugikan terpidana, maka sebaiknya dihapuskan saja ketentuan dari Pasal 263 ayat (3) KUHAP serta perlu dilakukan penyempurnaan kembali mengenai ketentuan Pasal 264 ayat (2) KUHAP.
\end{abstract}

Kata Kunci: Peninjauan kembali, perspektif, sistem peradilan pidana

\section{PENDAHULUAN}

Pada suatu negara yang berdasarkan kepada hukum, penerapan hukum haruslah disesuaikan menurut ketentuan hukum yang berlaku, oleh karena itu, semua warga negara dan juga lembaga negara harus tunduk dan terikat pada hukum. Penerapan hukum pada dasarnya merupakan suatu proses penegakan keadilan, meskipun tujuan hukum bukan hanya keadilan tetpi juga meliputi kepastian dan kemanfaatan. Akan tetapi, "tetap ada yang berpendapat di antara ketiga tujuan hukum itu keadilan merupakan tujuan yang paling penting". Bahkan di dalam doktrin Islam dikatakan oleh Marcel A. Boisard, bahwa: "Keadilan merupakan puat gerak dari nilai-nilai moral yang pokok". ii

Adapun salah satu sarana untuk mewujudkan keadilan dimaksud adalah dengan menggerakkan sistem peradilan pidana. Bergeraaknya sistem peradilan pidana di Indonesia, khususnya di kepolisian, kejaksaan dan pengadilan mengacu kepada Kitab Undang-undang Hukum Acara Pidana (KUHAP) kecuali jika ditentukan lain oleh undang-undang. ${ }^{\text {iii }}$ KUHAP yang diundangkan pada tanggal 31 Desember 1981, merupakan langkah awal pemerintah Indonesia untuk menggantikan Het Herziene Inlandsch (HIR) Reglement Staatsblads tahun 1941 Nomor 44. ${ }^{\text {iv }}$ Secara filosofis KUHAP adalah berlandaskan atau berpedoman kepada pancasila, terutama yang berhubungan erat dengan sila Ketuhanan dan Kemanusiaan. ${ }^{v}$

Hukum acara pidana di Indonesia mengenal adanya 2 (dua) upaya hukum, yang pertama adalah "upaya hukum biasa" dan yang kedua adalah "upaya hukum luar biasa". 
hukum biasa, kemudian terbagi lagi menjadi 2 (dua) bagian, yaitu "banding" dan "kasasi". Untuk pemeriksaan tingkat banding, hal mana sesuai menurut hukum, merupakan kewenangan dari Pengadilan Tinggi (PT) untuk memeriksa dan mengadili suatu perkara melalui Majelis Hakim Banding, dengan pengecualian terhadap putusan bebas (vrijspraak) Jaksa Penuntut Umum (JPU) tidak berhak mengajukan banding. Tetapi JPU dapat mengajukan permohonan kasasi dengan merujuk kepada yurisprudensi, tanggal 25 Desember 1983 Mahkamah Agung Reg. No. 275 K/Pid/1983. ${ }^{\text {vii }}$

Begitupun untuk upaya hukum luar biasa, adanya pembagian kembali atasnya- pun berlaku, pertama ialah "kasasi demi hukum" dan kedua merupakan "peninjauan kembali". Jika ditafsirkan dari sejarah, asal kata peninjauan kembali (PK) di terjemahkan dari Bahasa Belanda yaitu herziening.

Secara normatif, PK dapat diajukan dengan berpedoman kepada ketentuan Pasal 263 KUHAP yang menentukan bahwa:

1) Terhadap putusan pengadilan yang telah memperoleh kekuatan hukum tetap, kecuali putusan bebas atau lepas dari segala tuntutan hukum, terpidana atau ahli warisnya dapat mengajukan permintaan peninjauan kembali kepada Mahkamah Agung.

2) Permintaan peninjauan kembali dilakukan atas dasar:

(1) Apabila terdapat keadaan baru yang mmenimbulkan dugaan kuat bahwa jika keadaan itu sudah diketahui pada waktu sidang masih berlangsung, hasilnya akan berupa putusan bebas atau lepas dari segala tuntutan hukum atau tuntutan penuntut umum tidak dapat diterima atau terhadap perkara itu diterapkan ketentuan pidana yang lebih ringan;

(2) Apabila dalam berbagai putusan terdapat pernyataan bahwa sesuatu telah terbukti, akan tetapi hal atau keadaan sebagai dasar dan alasan putusan yang dinyatakan telah terbukti itu ternyata telah bertentangan satu dengan lainnya

(3) Apabila putusan itu dengan jelas memperlihatkan suatu kekhilafan hakim atau suatu kekeliruan yang nyata.

3) Atas dasar yang sama sebagaimana tersebut pada ayat (2) terhadap suatu putusan pengadilan yang telah memperoleh kekuatan hukum tetap dapat diajukan permintaan peninjauan kembali apabila dalam putusan itu suatu perbuatan yang didakwakan telah dinyatakan terbukti akan tetapi tidak diikuti oleh suatu pemidanaan.

Dalam penjelasan pasalnya, dinyatakan secara singkat pemahaman mengenai ketentuan pasal di atas, yaitu pasal ini memuat alasan secara limitatif untuk dapat dipergunakan meminta peninjauan kembali suatu putusan perkara pidana yang telah memperoleh kekuatan hukum tetap.

KUHAP setelah diberlakukan, khusus dalam hal pengabulan permohonan PK oleh MA, yang permohonannya adalah datang dari pihak JPU tidaklah pernah terjadi. Namun kenyataan berkata lain ketika sistem peradilan pidana dihadapkan pada suatu perkara Muchtar Pakpahan. Tetapi, pada beberapa tahun kemudian, MA menolak permohonan PK dari JPU dalam kasus Mulyar Bin Samsi. Pola praktik yang demikian ini terus berlanjut sampai sekarang, sehingga hukum yang mengatur mengenai PK dirasakan menjadi serba tak pasti. Akan adanya ketidakpastian ini, akhirnya muncullah berbagai macam pendapat di kalangan ahli hukum yang ada di Indonesia, yang sebelumnya hanya bersifat tak pasti berlanjut dengan sifat semakin tak pasti.

Apakah maksud ketentuan pada ayat (1) dari Pasal 263 KUHAP mengenai anak kalimat kecuali putusan bebas atau lepas dari segala tuntutan hukum itu? Jika pertanyaan ini dikaitkan dengan hak untuk mengajukan permohonan PK, tentunya akan dirasakan amat sangat membingungkan, mengenai hal yang membingungkan yang dimaksud yaitu: 
1) Tidaklah mungkin ada terpidana atau ahli warisnya, jika putusan pengadilan yang pada amar singkatnya dinyatakan bebas atau lepas sebagaimana telah dikecualikan untuk diajukan permohonan PK atasnya (yanga ada ialah terbebes atau terlepas dan bukannya terpidana atau ahli warisnya)

2) Manalah mungkin terhadap putusan yang berupa pembebasan atau pelepasan, dilakukan lagi perlawanan terhadapnya oleh pihak yang datang selain dari JPU yang telah jelas diuntungkan dengan adanya putusan tersebut, tanpa harus ditegaskan dengan pengecualian untuk diajukan permohonan PK terhadapnya.

Selanjutnya, apakah dengan tidak dituangkannya JPU secara tertulis pada ketentuan ayat (1) tersebut akan serta merta menjadikan JPU tidaklah mempunyai hak untuk mengajukan permohonan PK?

Kemudian bagaimana pula jika dihubungkan dengan ketentuan ayat (3) yang dinyatakan pada salah satu frasanya, suatu perbuatan yang didakwakan telah dinyatakan terbukti akan tetapi tidak diikuti oleh suatu pemidanaan tersebut?

Lebih lanjut terhadap putusan yang demikian itu (lepas) bukankah berarti tiada terpidananya? lalu apa pula hubungannya dengan terpidana atau ahli warisnya itu sendiri jika harus dikembalikan lagi pada ayat (1)? .

Sebenarnya untuk siapakah ketentuan ayat (3) tersebut diatur dalam upaya hukum PK? Menurut peneliti, denganadanya pengaturan mengenai ketentuan dari ayat tersebut tiada lain adalah untuk memberikan suatu hak kepada JPU dalam upaya nya menggunakan sarana PK.

Kemudian jika benar hal tersebut adalah benar, mengapa pula JPU tidak dinyatakan secara tertulis di dalam ketentuan Pasal 263 KUHAP dimaksud, dikarenakan pasal ini bersifat limitatif.

Dari beberapa pertanyaan tersebut dapatlah diketahui bahwa pada ketentuan Pasal 263 ayat (1) KUHAP yang pada salah satu anak kalimatnya, telah dinyatakan kecuali putusan bebas atau lepas dari segala tuntutan hukum telah bertentangan dengan istilahnya sendiri (contradictio in terminis) yang pada frasa berikutnya dirumuskan, terpidana atau ahli warisnya dapat mengajukan permintaan peninjauan kembali kepada Mahkamah Agung.

Antara ketentuan Pasal 263 ayat (1) KUHAP dengan Pasal 263 ayat (3) KUHAP telah terjadi pertentangan (konflik) norma, selain itu maksud atau arti dari ketentuan ayat (3) sangatlah luas pengertiannya (bermakna ganda), sehingga sangat sulit untuk dipahami atau dapat pula dimengerti kabur (vage normen) dikarenakan tidak adanya batasan yang tegas akan tujuan dari ayat dimaksud dirumuskan oleh para pembentuk undang-undang, untuk siapa dan apa pula rahasinya diatur sedemikian rupa dalam sistem upaya hukum luar biasa (PK) itu sendiri.

Beranjak dari keadaan di atas maka penulis tertarik untuk melakukan kajian ilmiah tentang Pengaturan Peninjauan Kembali Dalam Perspektif Sistem Peradilan Pidana Di Indonesiaagar nantinya diperoleh suatu gambaran tentang pengaturan peninjauan kembali dalam perpektif sistem peradilan pidana di Indonesia. Untuk membatasi kajian penelitian, maka permasalahan dibatasi pada persoalan yang dianggap sangat mendasar, yaitu:

1. Bagaimanakah permohonan Peninjauan Kembali (PK) yang diajukan oleh Jaksa Penuntut Umum dalam perspektif sistem peradilan pidana?

2. Bagaimanakah pengaturan Peninjauan Kembali (PK) dalam perspektif sistem peradilan pidana di Indonesia untuk kedepannya?

\section{TINJAUAN PUSTAKA}

\subsection{Peninjauan Kembali (PK)}

Untuk mencari batasan dari Peninjauan Kembali (PK) tidaklah dapat dikemukakan di dalam KUHAP maupun peraturan perundang-undangan lainnya, namun jika merujuk kepada KUHAP 
semata, maka dapatlah diketahui bahwa KUHAP telah memberikan suatu pegangan pokok mengenai upaya hukum PK sebagai berikut:

1) Hak terpidana atau ahli warisnya untuk mengajukan permohonan PK (Pasal 1 angka 12 KUHAP);

2) Terhadap putusan pengadilan yang telah memperoleh kekuatan hukum tetap yang berisi pemidanaan (Pasal 263 ayat (1) KUHAP);

3) Tidak dibatasi oleh jangka waktu (Pasal 264 ayat (3) KUHAP;

4) Permohonan dilakukan (dimohonkan) hanya 1 (satu) kali (Pasal 268 ayat (3) KUHAP);

5) Jika dikabulkannya permohonan tersebut, maka putusan yang dijatuhkan seminimal mungkin tidak melebihi pidana yang dijatuhkan dalam putusan semula (Pasal 266 ayat (3) KUHAP).

Kemudian merujuk kepada pendapat para ahli hukum, dimana secara singkat telah diartikan Soedirjo bahwa PK merupakan "suatu upaya hukum yang dipakai untuk memperoleh penarikan kembali atau perubahan terhadap putusan hakim yang pada umumnya tidak dapat diganggu gugat lagi". viii

Hal yang lebih singkat lagi dikemukakan oleh Trimoelja D. Soerjadi, "Peninjauan Kembali adalah suatu upaya hukum luar biasa untuk dapat merubah atau memperbaiki putusan pengadilan yang mengandung kesesatan hakim". ix

\subsection{Sistem Peradilan Pidana}

Seorang kebangsaan Amerika Serikat yang bernama Frank Remington memperkenalkan konsep "rekayasa administrasi peradilan pidana melalui pendekatan sistem (System approach) dan gagasan mengenai sistem ini terdapat pada laporan pilot proyek tahun 1958. Gagasan ini kemudian diletakkan pada mekanisme administrasi peradilan pidana dan diberi nama Criminal Justice System". ${ }^{2}$

Pada dasarnya istilah "criminal justice system" atau sistem peradilan pidana menunjukkan mekanisme kerja dalam penaggulangan kejahatan dengan mempergunakan dasar pendekatan sistem. ${ }^{\mathrm{xi}}$

Selanjutnya pendapat yang lebih sederhana mengenai batasan dari sistem peradilan pidana dikemukakan oleh Mardjono Reksodipoetro adalah "suatu sistem pengendalian kejahatan yang terdiri atas lembaga-lembaga kepolisian, kejaksaan, pengadilan dan pemasyarakatan terpidana". xii

Lebih lanjut, Soerjono Soekanto menyatakan bahwa: "Sistem Peradilan Pidana merupakan suatu keseluruhan yang terangkai yang terdiri atas unsur-unsur yang saling berhubungan secara fungsional, sistem peradilan pidana tersebut terdiri atas unsur-unsur yang masing-masing merupakan sub sistem dari sistem tersebut". ${ }^{1}$

\section{METODE PENELITIAN}

Penelitian ini merupakan penelitian hukum yuridis normatif, sifat normatif penelitian hukum dikaitkan dengan karakter keilmuan itu sendiri. Karena itu pemilihan metode penelitian senantiasa dibatasi oleh rumusan masalah, objek yang diteliti dan tradisi keilmuan hukum itu sendiri.

Pendekatan penelitian yang digunakan dalam penelitian ini adalah pendekatan perundang-undangan (statute approach) dilakukan dengan cara menelaah semua undangundang yang saling berkaitan dengan isu hukum yang diteliti, pendekatan kasus (case law approach) dilakukan dengan cara melakukan telaah terhadap pertimbangan dari Mahkamah

${ }^{1}$ Ibid., hal. 38. 
Agung dalam mengabulkan permohonan Peninjauan Kembali yang berkaitan dengan isu yang dihadapi dan pendekatan konseptual (conceptual approach) dilakukan dengan cara menelaah pandangan-pandangan dari doktrin-doktrin yang berkembang di dalam ilmu hukum.

Dalam penelitian ini bahan-bahan hukum yang digunakan antara lain:

1) Bahan hukum primer

Bahan hukum primer adalah bahan-bahan hukum yang dijadikan dasar dalam menyusun penulisan penelitian yang diambil dari kepustakaan, diantaranya yaitu Undang-Undang Nomor 8 Tahun 1981 tentang Kitab Undang-undang Hukum Acara Pidana .

2) Bahan hukum sekunder

Bahan hukum sekunder adalah bahan yang memberikan penjelasan mengenai bahan hukum primer, diantaranya yaitu diperoleh dengan mempelajari buku-buku, majalah, hasil penelitian, laporan kerja dan lain-lain yang berkaitan dengan penelitian ini.

Analisis bahan hukum dilakukan dengan cara:

(1) Menginterpretasikan semua peraturan perundang-undangan sesuai masalah yang dibahas.

(2) Menilai bahan-bahan yang berhubungan dengan masalah yang akan diteliti.

(3) Mengevaluasi perundang-undangan yang berhubungan dengan masalah yang dibahas.

\section{HASIL DAN PEMBAHASAN}

\subsection{Permohonan Peninjauan Kembali Oleh Jaksa Penuntut Umum Dalam Perspektif Sistem Peradilan Pidana di Indonesia.}

Secara normatif, Peninjauan Kembali (PK) dapat diajukan dengan berpedoman kepada ketentuan Pasal 263 KUHAP, yang isinya sebagai berikut:

1) Terhadap putusan pengadilan yang telah memperoleh kekuatan hukum tetap, kecuali putusan bebas atau lepas dari segala tuntutan hukum, terpidana atau ahli warisnya dapat mengajukan permintaan peninjauan kembali kepada Mahkamah Agung.

2) Permintaan peninjuan kembali dilakukan atas dasar:

(1) Apabila terdapat keadaan baru yang menimbulkan dugaan kuat bahwa jika keadaan itu sudah diketahui pada waktu sidang masih berlangsung, hasilnya akan berupa putusan bebas atau lepas dari segala tuntutan hukum atau tuntutan penuntut umum tidak dapat diterima atau terhadap perkara itu diterapkan ketentuan pidana yang lebih ringan;

(2) Apabila dalam berbagai putusan terdapat pernyataan bahwa sesuatu telah terbukti, akan tetapi hal atau keadaan sebagai dasar dan alasan putusan yang dinyatakan telah terbukti itu, ternyata telah bertentangan satu dengan yang lainnya;

(3) Apabila putusan itu dengan jelas memperlihatkan suatu kekhilafan hakim atau suatu kekeliruan yang nyata.

3) Atas dasar yang sama sebagaimana tersebut pada ayat (2) terhadap suatu putusan pengadilan yang telah memperoleh kekuatan hukum tetap dapat diajukan permintaan peninjauan kembali apabila dalam putusan itu suatu perbuatan yang didakwakan telah dinyatakan terbukti akan tetapi tidak diikuti oleh suatu pemidanaan. 
Apakah pengajuan permohonan PK oleh JPU terhadap putusan bebas atau lepas dapat menempatkan JPU sebagai pihak yang telah melakukan penyalahgunaan wewenang dalam hukum acara? Atau apakah justru pengabulan permohonan PK oleh MA itulah yang dimaksud dengan penyalahgunaan wewenang dalam sistem peradilan pidana?

Untuk menjawab pertanyaan tersebut, JPU bisa saja berpedoman kepada asas similis similius, dengan suatu pertimbangan bahwa hukum tidak akan memberikan hak secara timpang, baik kepada terpidana atau ahli warisnya, maupun kepada JPU dalam upayanya membangun suatu suatu keyakinan kepada majelis hakim PK pada saat menjatuhkan putusan nantinya, baik berupa putusan bebas, lepas maupun berupa pemidanaan yang lebih berat sekalipun.

Selanjutnya jika benar pendapat yang dibangun berdasarkan asas tersebut tidaklah tepat, bukankah berarti keyakinan dari JPU dalam upayanya mencari kebenaran dan keadilan akan terhalang atau untuk jelasnya keyakinan dimaksud haruslah diabaikan ditingkat PK.

Untuk mengetahui keberadaan JPU dalam kapasitasnya mengajukan permohonan PK adalah berpedoman kepada ketentuan Pasal 263 KUHAP, yang selanjutnya peneliti menafsirkan dengan memulainya dari ketentuan ayat (1) yang dirumuskan, “.... terpidana atau ahli warisnya dapat mengajukan permintaan peninjauan kembali kepada Mahkamah Agung”.

Akan adanya terpidana atau ahli warisnya tanpa menyatakan JPU secara tegas, tentunya telah dapat diartikan bahwa JPU tidak mempunyai hak untuk mengajukan permohonan PK.

Selanjutnya dikaitkan dengan ayat (3) yang tertuang, "Atas dasar yang sama sebagaimana tersebut pada ayat (2).... dapat diajukan permintaan peninjauan kembali apabila dalam putusan itu suatu perbuatan yang didakwakan telah dinyatakan terbukti akan tetapi tidak diikuti oleh suatu pemidanaan”.

Untuk siapakah sebenarnya ketentuan dari ayat (3) ini ditur dalam upaya hukum PK? Tentunya jawaban yang paling tepatbukanlah untuk terpidana atau ahli warisnya. Oleh karena itu, untuk siapa lagi kalau bukan untuk JPU.

Akan adanya keadaan yang demikian ini, maka dapatlah diketahui bahwa terhadap putusan yang dikecualikan oleh terpidana atau ahli warisnya untuk diajukan permohonan PK atasnya itu, maka dengan sendirinya di dalam mengisis kekosongan dari pengecualian dimaksud JPU lah yang paling berkepentingan untuk mengisinya.

Argumen ini kemudian dihadapkan kembali kepada permasalahan lainnya, dimana permasalahan tersebut adalah mengenai putusan bebas dikarenakan pengecualian oleh ketentuan Pasal 263 ayat (1) KUHAP tersebut bukan hanya berlaku untuk putusan lepas, namun berlaku pula untuk putusan bebas.

Kemudian, bagaimana pula terhadap putusan bebas itu sendiri?, Pasal 244 KUHAP secara tegas dinyatakan bahwa putusan bebas tidaklah dapat dimohonkan kasasi yang juga berarti terhadap putusan lepas akan berlaku pula hal yang sama. Namun hal yang perlu diingat, bahwa putusan bebas lebih mulia dari putusan lepas. Oleh karenanya, terhadap putusan lepas dapat diajukan permohonan PK oleh JPU dengan niat agar terlepas dibebaskan ditingkat PK.

Apakah mungkin JPU mengajukan permohonan PK untuk membebaskan terlepas? Jawabnya mungkin, dikarenakan JPU telah terlebih dahulu menemukan atau mengetahui adanya syarat-syarat materil utnuk mengajukan permohonan PK sebagimana telah digariskan oleh ketentuan Pasal 263 ayat (2) KUHAP dan Pasal 263 ayat (3) KUHAP.

\subsection{Pengaturan Peninjauan Kembali Dalam Perspektif Sistem Peradilan Pidana Di Indonesia Untuk Kedepannya.}

Mengacu kepada ketentuan Pasal 263 RUU KUHAP yang menentukan:

1) Setelah berkas permohonan peninjauan kembali diterima, Ketua Mahkamah Agung atau Hakim Agung yang ditunjuk memeriksa permohonan tersebut dan menetapkan 
permohonan peninjauan kembali telah memenuhi ketentuan sebagaimana dimaksud dalam Pasal 258 ayat (3).

2) Dalam memeriksa permohonan peninjauan kembali,Mahkamah Agung memutus dalam sidang pleno yang dipimpin oleh Ketua Mahkamah Agung.

3) Dalam hal Mahkamah Agung berpendapat bahwa permohonan peninjauan kembali dapat diterima untuk diperiksa, berlaku ketentuan sebagai berikut:

(1) Apabila Mahkamah Agung tidak membenarkan alasan pemohon, Mahkamah Agung menolak permohonan peninjauan kembali dengan menetapkan bahwa putusan yang dimohonkan peninjauan kembali itu tetap berlaku disertai dasar pertimbangnnya;

(2) Apabila Mahkamah Agung membenarkan alasan pemohon, Mahkamah Agung membatalkan putusan yang dimohonkan peninjauan kembali dan melimpahkan perkara kepada pengadilan negeri yang memutuskan perkara dan pengadilan negeri tersebut menjatuhkan putusan berupa:
(a) Putusan bebas
(b) Putusan lepas dari segala tuntutan hukum;
(c) Putusan yang menyatakan tuntutan penuntut umum tidak dapat diterima; atau
(d) Putusan dengan menerapkan ketentuan pidana yang lebih ringan.

1) Pidana yang dijatuhkan dalam putusan peninjauan kembali tidak boleh melebihi pidana yang telah dijatuhkan dalam putusan yang dimintakan peninjauan kembali.

2) Apabila terpidana telah menjalani putusan yang diajukan peninjauan kembali dan ternyata putusan peninjauan kembali membebaskan, melepaskan dari segala tuntutan hukum, putusan tidak dapat menerima tuntutan Penuntut Umum atau putusan dengan menerapkan ketentuan pidana yang lebih ringan, maka pemohon peninjauan kembali atau ahli warisnya wajib diberikan ganti kerugian dan rehabilitasi.

3) Ketentuan lebih lanjut mengenai tata cara pemberian ganti kerugian dan rehabilitasi diatur dengan peraturan pemerintah.

Memperhatikan ketentuan pasal sebagaimana tersebut di atas, maka dapat diketahui adanya perubahan mendasar dalam KUHAP, khususnya pada ketentuan Pasal 263 ayat (2) RUU KUHP yang tidaklah dapat diketemukan rumusan yang demikian itu dalam KUHAP.

Begitupun terhadap ketentuan Pasal 263 ayat (3) huruf b RUU KUHAP terdapat perbedaan mendasar dengan ketentuan Paal 266 ayat (2) huruf b KUHAP, dalam hal mana KUHAP mengenal penjatuhan putusan PK dilakukan oleh MA, sementara pada ketentuan Pasal 263 ayat (3) huruf b RUU KUHAP MA hanya bertindak untuk membatalkan putusan yang dimohonkan PK, kemudian melimpahkan perkara kepada PN yang memutuskan perkara ini, dan untuk selanjutnya PN tersebut menjatuhkan putusan sesuai dengan petunjuk yang dihasilkan dari adanya sidang pleno yang dipimpin oleh ketua MA.

Pada ketentuan Pasal 263 ayat (5) RUU KUHAP tidak dapat dijumpai dalam KUHAP, ketentuan ini sangatlah baik dan tegas. Pada ketentuan Paal 263 ayat (4) RUU KUHAP pada dasarnya sama dengan ketentuan Pasal 266 ayat (3) KUHAP, hanya saja perumusan dari ketentuan Pasal 263 ayat (4) RUU KUHAP lebih tegas, karena pada anak kalimatnya dapat dijumpai "dalam putusan yang dimintakan peninjauan kembali" yang tidak dapat diketemukan dalam ketentuan Pasal 266 ayat (3) KUHAP, tetapi hanya menyatakan pada anak kalimatnya dalam "putusan semula" yang susah untuk dipahami oleh masyarakat yang awam akan hukum.

Pada ketentuan Pasal 263 ayat (3) huruf a RUU KUHAP sama dengan rumusan dari ketentuan Pasal 266 ayat (2) huruf a KUHAP, hanya saja istilah permintaan diganti dengan permohonan, serta istilah dimintakan dirubah dengan dimohonkan. Rumusan ketentuan Pasal 
263 ayat (3) huruf a RUU KUHAP lebih benar jika dibandingkan dengan ketentuan Pasal 266 ayat (2) huruf a KUHAP. Untuk jelasnya dapat dikatakan lebih konsisten.

Untuk pembahasan terakhir dalam menguraikan rumusan ius constituendum dimaksud, di dalam ketentuan Pasal 264 dipaparkan:

1) Kecuali untuk pelaksanaan pidana mati, pemusnahan, perusakan barang bukti, permohonan peninjauan kembali atas suatu putusan tidak menangguhkan atau menghentikan pelaksanaan dari putusan tersebut.

2) Dalam hal permohonan peninjauan kembali sudah diterima oleh Mahkamah Agung dan pemohon meninggal dunia, mengenai diteruskan atau tidaknya peninjauan kembali tersebut diserahkan kepada ahli warisnya.

Ketentuan Pasal 264 ayat (1) RUU KUHAP merupakan penjabaran lebih lanjut dari ketentuan Pasal 268 ayat (1) KUHAP, sementara ketentuan dari Pasal 264 ayat (2) RUU KUHAP sama dengan ketentuan pada Pasal 268 ayat (2) KUHAP.

Berikutnya merujuk kembali kepada KUHAP, menurut peneliti pengaturan mengenai PK untuk kedepannya, jika memang pembentuk undang-undang berkehendak untuk menghilangkan hak JPU pada perbendaharaan KUHAP dalam kapasitasnya menggunakan sara PK, maka rumusan dari ketentuan Pasal 263 KUHAP idealnya menjadi seperti berikut:

1) Terhadap putusan pengadilan yang telah memperoleh kekuatan hukum tetap, terpidana atau ahli warisnya dapat mengajukan permintaan peninjauan kembali kepada Mahkamah agung.

2) Permintaan peninjauan kembali dilakukan atas dasar:

(1) Apabila terdapat keadaan baru yang menimbulkan dugaan kuat bahwa jika keadaan itu sudah diketahui pada waktu sidang masih berlangsung, hasilnya akan berupa putusan bebas atau lepas dari segala tuntutan hukum atau tuntutan penuntut umum tidak dapat diterima atau terhadap perkara itu diterapkan ketentuan pidana yang lebih ringan;

(2) Apabila dalam berbagai putusan terdapat pernyataan bahwa sesuatu telah terbukti, akan tetapi hal atau keadaan sebagai dasar dan alasan putusan yang dinyatakan telah terbukti itu, ternyata telah bertentangan satu dengan lainnya;

(3) Apabila putusan itu dengan jelas memperlihatkan suatu kekhilafan hakim atau suatu kekeliruan yang nyata.

Namun, menurut peneliti ada baiknya jika JPU diberikan pula hak secara berimbang denganterpidana dalam upayanya meyakinkan majelis hakim PK. Jika JPU diberikan hak untuk menagjkan permohonan PK dalam sistem peradilan Pidana, tentunya di dalam KUHAP akan diketemukan rumusan Pasal 263 KUHAP menjadi:

1) Terhadap putusan pengadilan yang telah memperoleh kekuatan hukum tetap, kecuali putusan bebas atau lepas dari segala tuntutan hukum, terpidana atau ahli warisnya maupun jaksa penuntut umum dapat mengajukan permohonan peninjauan kembali kepada Mahkamah Agung.

2) Permintan peninjauan kembali dilakukan atas dasar:

(1) Apabila terdapat keadaan baru yang menimbulkan dugaan kuat bahwa jika keadaan itu sudah diketahui pada waktu sidang masih berlangsung, hasilnya akan menjadi lain dengan putusan yang telah dijatuhkan;

(2) Apabila dalam berbagai putusan terdapat pernyataan bahwa sesuatu telah terbukti maupun tdak terbukti, akan tetapi hal atau keadaan sebagai dasar dan alasan putusan yang dinyatakan telah terbukti maupun tidak terbukti itu, ternyata telah bertentangan satu dengan lainnya;

(3) Apabila putusan itu dengan jelas memperlihatkan suatu kekhilafan hakim atau suatu kekeliruan yang nyata.

Kemudian di dalam ketentuan Pasal 266 ayat (2) huruf b KUHAP dituangkan: 
Apabila Mahkamah Agung membenarkan alasan pemohon, Mahkamah Agung membatalkan putusan yang dimintakan peninjauan kembali itu dan menjatuhkan putusan yang dapat berupa:

1) Putusan bebas;

2) Putusan lepas dari segala tuntutan hukum;

3) Putusan tidak dapat menerima tuntutan jaksa penuntut umum;

4) Putusan dengan menerapkan ketentuan pidana yang lebih berat atau yang lebih ringan.

Sementara untuk ketentuan Pasal 266 ayat (3) KUHAP dihapuskan, serta ketentuan Pasal 244 KUHAP menjadi: Terhadap putusan perkara pidana yang diberikan pada tingkat terakhir oleh pengadilan lain selain dari pada Mahkamah Agung, terdakwa atau jaksa penuntut umum dapat megajukan permintaan pemeriksaan kasasi kepada Mahkamah Agung kecuali terhadap putusan bebas atau lepas.

\section{Kesimpulandan Saran}

Dalam perspektif sistem peradilan pidana di Indonesia, Jaksa Penuntut Umum berhak mengajukan permohonan Peninjauan Kembali (PK) terhadap putusan yang telah berkekuatan hukum tetap, dengan prinsip dasarnya yang diajukan tersebut menguntungkan terpidana atau ahli warisnya. Namun hal ini tidaklah bersifat mutlak, karena dalam hal tertentu dapat pula diajukan permohonan PK oleh Jaksa Penuntut Umum terhadap putusan yang telah berkekuatan hukum tetap jika idak terwujudnya kebenaran materil, sehingga permohonan PK tersebut kemungkinan besar justru akan memberatkan terpidana.

Pengaturan upaya hukum PK dalam perspentif sistem peradilan pidana yang ideal kedepannya adalah supaya Jaksa Penuntut Umum diberi hak secara tegas untuk mengajukan permohonan PK di dalam ketentuan Pasal 263 KUHAP, baik dalam kapasitasnya untuk meringankan maupun memberatkan terpidana. Serta ditambahkan pula di dalam ketentuan pasal yang mengatur mengenai PK akan kewajiban dari Jaksa Penuntut Umum untuk memberitahukan kepada terpidana atau ahli warisnya, bilamana mengethui terlabih dahulu mengenai syarat-syarat materil yang dapat menguntungkan terpidana atau ahli warisnya.

Dalam perspektif sistem peradilan pidana di Indonesia hendaknya antara terpidana dan Jaksa Penuntut Umum diberikan hak secara berimbang di dalam upayanya menggunakan sarana hukum Peninjauan Kembali.Jika pembentuk undang-undang menghendaki adanya penghilangan hak dari Jaksa Penuntut Umum di dalam upayanya mengajukan permohonan PK secara tuntas, yang sekiranya dapat merugikan terpidana, maka sebaiknya dihapuskan saja ketentuan dari Pasal 263 ayat (3) KUHAP serta perlu dilakukan penyempurnaan kembali mengenai ketentuan Pasal 264 ayat (2) KUHAP.

\section{DAFTAR PUSTAKA \\ Buku}

Ahmad Rifai, 2010, Penemuan Hukum Oleh Hakinm Dalam Perspektif Hukum Progresif, Cet. Pertama, Sinar Grafika, Jakarta.

Ahmad Kamil dan M. Fauzan, 2008, Kaidah-kaidah Hukum Yurisprudensi, Cet. Ketiga, Kencana Prenada Media Group, Jakarta.

Al. Wisnubroto dan G. Widiartama, 2005, Pembaharuan Hukum Acara Pidana, Cet. Pertama, Citra Aditya Bakti, Bandung.

Andi Hamzah, 2001, Hukum Acara Pidana Indonesia, Cet. Ketiga, Sinar Grafika, Jakarta.

Barda Nawawi Arief, 2008, Masalah Penegakan Hukum Dan Kebijakan Hukum Pidana Dalam Penanggulangan Kejahatan, Cet. Kedua, Kencana, Jakarta. 
Darji Darmodiharjo dan Shidarta, 2004, Pokok-Pokok Filsafat Hukum, Cet. Kelima, Gramedia Pustaka Utama, Jakarta.

Darwan Prinst, 2003, Peradilan Militer, Cet. Pertama, Citra Aditya Bakti, Bandung.

Lilik Mulyadi, 2007, Hukum Acara Pidana: Suatu Tinjauan Khusus Terhadap Surat Dakwaan, Eksepsi da Putusan Peradilan, Cet. Ketiga, Citra Aditya Bakti, Bandung.

Leden Marpaung, 2004,Perumusan Memori Kasasi dan Peninjauan Kembali Perkara Pidana, Cet. Kedua, Sinar Grafika, Jakarta.

M. Yahya Harahap, 2006,Pembahasan Permasalahan Dan Penerapan KUHAP: Penyidikan dan penuntutan, Cet. Kedelapan, Sinar Grafika, Jakarta.

Muhammad Tahir Azhary, 2004, Negara Hukum: Suatu Studi Tentang Prinsip-Prinsipnya Dilihat Dari Segi Hukum Islam, Implementasinya Pada Periode Negara Madinah Dan Masa Kini, Cet. Kedua, Prenada Media, Jakarta.

Romli Atmasasmita, 1996, Sistem Peradilan Pidana: Perspektif Eksistensialisme dan Abolisioisme, Cet. Kedua, Putra A. Bardin, Jakarta.

Soedirjo, 1986, Peninjauan Kembali Dalam Perkara Pidana: Arti Dan Makna, Cetakan Pertama, Melton Puta, Jakarta.

Trimoelja D. Soerjadi, 2004, Kendala Menegakkan Kebenaran dan Keadilan, Cetakan Pertama, Guna Widya, Surabaya.

\section{Peraturan Perundang-Undangan}

Kitab Undang-Undang Hukum Acara Pidana (KUHP)

Undang-Undang Republik Indonesia Nomor 19 Tahun 1964 Tentang Ketentuan-Ketentuan Pokok Kekuasaan Kehakiman.

Undang-Undang Republik Indonesia Nomor 13 Tahun 1965 Tentang Pengadilan dalam Lingkungan Peradilan Umum dan Mahkamah Agung.

Undang-Undang Republik Indonesia Nomor 14 Tahun 1970 Tentang Ketentuan-Ketentuan Pokok Kekuasaan Kehakiman.

\section{Footnote}

${ }^{\mathrm{i}}$ Darji Darmodiharjo dan Shidarta, Pokok-Pokok Filsafat Hukum, Cet. Kelima, Gramedia Pustaka Utama, Jakarta, 2004, hal. 155

${ }^{i i}$ Muhammad Tahir Azhary, Negara Hukum: Suatu Studi Tentang Prinsip-Prinsipnya Dilihat Dari Segi Hukum Islam, Implementasinya Pada Periode Negara Madinah Dan Masa Kini, Cet. Kedua, Prenada Media, Jakarta, 2004, hal. 121.

iiiLilik Mulyadi, Hukum Acara Pidana: Suatu Tinjauan Khusus Terhadap Surat Dakwaan, Eksepsi da Putusan Peradilan, Cet. Ketiga, Citra Aditya Bakti, Bandung, 2007, hal. 2-3.

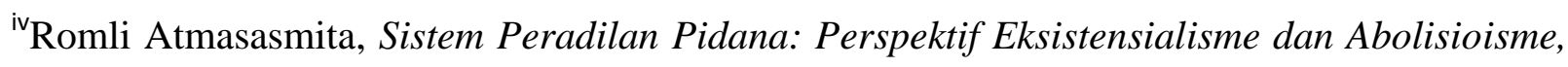
Cet. Kedua, Putra A. Bardin, Jakarta, 1996, hal. 39.

${ }^{\text {v} M . ~ Y a h y a ~ H a r a h a p, ~ O p . ~ C i t ., ~ h a l . ~} 20$. 
${ }^{v i}$ Ahmad Kamil dan M. Fauzan, Kaidah-kaidah Hukum Yurisprudensi, Cet. Ketiga, Kencana Prenada Media Group, Jakarta, 2008, hal. 48.

\section{vii Ibid.}


Melton Puta, Jakarta, 1986, hal. 11.

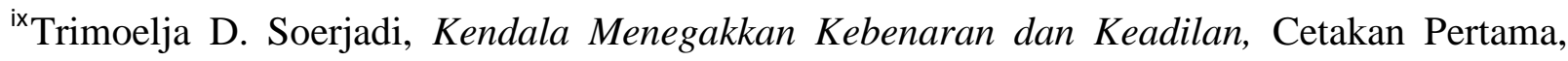
Guna Widya, Surabaya, 2004, hal. 3.

${ }^{x}$ Yesmil Anwar dan Adang, Sistem Peradilan Pidana: Konsep, Komponen, dan Pelaksanaannya Dalam Penegakan Hukum Di Indonesia, Cet. Pertama, Widya Padjadjaran, Bandung, 2009, hal. 33.

${ }^{\mathrm{xi}}$ Faisal, Menerobos Positivisme Hukum, Cetakan Pertama, Rangkang Education, Yogyakarta, 2010, hal. 26.

xii Yesmil Anwar dan Adang, Op. Cit., hal. 35. 